\title{
Importance of factor-IX-dependent prothrombinase formation - the Josso Pathway,- in clotting plasma
}

Citation for published version (APA):

Xi, M., Beguin, S., \& Hemker, H. C. (1989). Importance of factor-IX-dependent prothrombinase formation the Josso Pathway,- in clotting plasma. Haemostasis, 19(6), 301-308. https://doi.org/10.1159/000216034

Document status and date:

Published: 01/01/1989

DOI:

10.1159/000216034

Document Version:

Other version

\section{Please check the document version of this publication:}

- A submitted manuscript is the version of the article upon submission and before peer-review. There can be important differences between the submitted version and the official published version of record.

People interested in the research are advised to contact the author for the final version of the publication, or visit the DOI to the publisher's website.

- The final author version and the galley proof are versions of the publication after peer review.

- The final published version features the final layout of the paper including the volume, issue and page numbers.

Link to publication

\footnotetext{
General rights rights.

- You may freely distribute the URL identifying the publication in the public portal. please follow below link for the End User Agreement:

www.umlib.nl/taverne-license

Take down policy

If you believe that this document breaches copyright please contact us at:

repository@maastrichtuniversity.nl

providing details and we will investigate your claim.
}

Copyright and moral rights for the publications made accessible in the public portal are retained by the authors and/or other copyright owners and it is a condition of accessing publications that users recognise and abide by the legal requirements associated with these

- Users may download and print one copy of any publication from the public portal for the purpose of private study or research.

- You may not further distribute the material or use it for any profit-making activity or commercial gain

If the publication is distributed under the terms of Article $25 \mathrm{fa}$ of the Dutch Copyright Act, indicated by the "Taverne" license above, 


\title{
Original Papers
}

\section{Importance of Factor-IX-Dependent Prothrombinase Formation - The Josso Pathway - in Clotting Plasma}

\author{
Ma Xia , S. Béguin b, H.C. Hemker ${ }^{\mathrm{b}}$ \\ a Hematologic Institute of Xian, People's Republic of China; \\ ${ }^{b}$ Department of Biochemistry, Biomedical Center, University of Limburg, Maastricht, The Netherlands
}

Key Words. Prothrombinase · Factor IX · Coagulation · Thromboplastin · Josso pathway

Abstract. We report a study on the importance of factor IX activation in thromboplastindependent coagulation in plasma. Diluted, $\mathrm{CaCl}_{2}$-containing thromboplastin solutions at constant phospholipid concentration were used to trigger the coagulation in plasma from patients with congenital factor IX and factor VIII deficiency in the presence and absence of added factors IX and VIII, and the generation of thrombin activity was monitored. When coagulation is triggered with the high thromboplastin concentrations normally used in clinical routine tests, the generation of thrombin activity in plasma of patients with congenital factor IX deficiency before and after reconstitution with purified factor IX appears identical. When, however, coagulation is triggered with low thromboplastin concentrations, a clear dependency of the generation of thrombin activity on the concentration of factor IX becomes evident at factor IX concentrations lower than $30 \mathrm{n} M$ (about $40 \%$ clotting factor activity). Factor VIII is a compulsory cofactor for this factor IX activity because the prothrombinase activity at optimal factor IX concentration is still critically dependent upon the amount of factor VIII present. The lower the amount of thromboplastin, the higher the importance of factor IX and factor VIII activation in thromboplastin-dependent coagulation. This suggests a role of this pathway in pathophysiological thrombin formation.

\section{Introduction}

In the classical view, factor $\mathrm{X}$ can be activated via two distinct pathways: the intrinsic pathway and the extrinsic pathway $[1,2]$. The intrinsic pathway is initiated by the so-called contact activation, which is triggered when blood comes in contact with foreign surfaces such as glass $[3,4]$. The initial steps of this pathway involve the four contact factors (factor XII, prekallikrein, high-molecular-weight kininogen, factor XI), and the two antihemophilic factors (factors IX and VIII).

The extrinsic pathway is initiated when blood is exposed to tissue thromboplastin. The reaction sequence involves interaction 
of factor VII and tissue thromboplastin and subsequent activation of factor $\mathrm{X}$ [5]. Thus both classical pathways converge in the activation of factor $\mathrm{X}$. The conversion of prothrombin to thrombin and that of fibrinogen to fibrin, are common to both pathways.

Evidence for a close interrelationship of the classical coagulation pathways has accumulated, however. Biggs and Nossel [6] found that hemophilic plasma did not generate normal amounts of thrombin activity when plasma coagulation was triggered with a diluted thromboplastin solution. Josso and Prou-Wartelle [7] stated that factor VII was essential for the procoagulant activity of diluted thromboplastin and postulated the importance of antihemophilic factors in the thromboplastin-dependent pathway [7]. Direct evidence for a possible linkage between both classical pathways was obtained by Østerud and Rapaport [8]. They clearly showed that a mixture of factor VII and thromboplastin could activate factor IX in a partially purified system. This activation step was studied further by several groups, and it was clearly shown that factor VIIa in the presence of thromboplastin can activate both factor IX and factor X [9-14].

Although numerous studies have postulated that the factor IX activation in thromboplastin-dependent coagulation is important, attention has mostly focussed on factor $\mathrm{X}$ activation in purified systems. Clear evidence as to what extent the generation of thrombin in plasma is mediated via thromboplastin-induced factor IX activation is lacking. In fact, the importance of the factorIX-dependent reinforcement loop in the extrinsic pathway has been questioned [15]. In order to obtain a better impression of the relative importance of the thromboplastin-induced factor IX activation during the clot- ting of normal plasma we studied the effect of thromboplastin concentration on the generation of thrombin activity in factor-IXand factor-VIII-deficient plasma spiked with different concentrations of purified factor IX and factor VIII. Due to a recently developed technique, we could quantitate their effects on thrombin generation in terms of prothrombinase activity [16]. With this method, the prothrombin conversion velocity (i.e. the prothrombinase activity) as a function of time is calculated from the thrombin generation curve. The basis of the method is that at any moment the observed thrombin generation velocity $(\mathrm{g})$ is the sum of the prothrombin conversion velocity $(p)$ and the negative thrombin breakdown velocity (b). The breakdown velocity can be calculated from the amount of thrombin present and the breakdown constants of thrombin in plasma. Once this velocity is known, the prothrombin conversion can be calculated as the sum of $g$ and $b(p=g+b)$.

\section{Materials and Methods}

\section{Hemophiliacs}

Diagnosis of both hemophilia A and B was based on a positive family history with a recessive sexlinked inheritance, joint and deep muscle bleeding and a prolonged partial thromboplastin time. The activity of the clotting factors VIII and IX was quantitatively determined by a one-stage method according to Josso and Prou-Wartelle [17]. The factor VIII activity in hemophilia A plasma and the factor IX activity in hemophilia B plasma were $<0.8$ and $1.5 \%$, respectively.

\section{Hemophilic Plasma}

Blood from hemophiliacs (A and B) was collected in trisodium citrate ( $9 \mathrm{vol}$ of blood to $1 \mathrm{vol}$ of $0.13 \mathrm{M}$ trisodium citrate) and centrifuged twice for $15 \mathrm{~min}$ at $3,000 \mathrm{~g}$ at $15^{\circ} \mathrm{C}$, and then for $60 \mathrm{~min}$ at $23,000 \mathrm{~g}$ at $4{ }^{\circ} \mathrm{C}$. Plasma was stored in $1-\mathrm{ml}$ aliquots at $-80^{\circ} \mathrm{C}$. 


\section{Thromboplastin}

Human brain thromboplastin was prepared by a modification of the method of Owren and Aas [18]. The crude preparation obtained was homogenized in a Potter-Elvehjem homogenizer for $3 \mathrm{~min}$ and centrifuged for $15 \mathrm{~min}$ at $2,000 \mathrm{~g}$ at room temperature. The preparation was stored in $0.1-\mathrm{ml}$ aliquots at $-20^{\circ} \mathrm{C}$. Prior to use, it was thawed, diluted with $0.05 \mathrm{M}$ Tris$\mathrm{HCl}$ (pH 7.35) containing $0.1 \mathrm{M} \mathrm{CaCl} 2$ and prewarmed for $1 \mathrm{~h}$ at $37^{\circ} \mathrm{C}$. The $1 / 40$ diluted thromboplastin gave a clotting time of $80 \mathrm{~s}$ with normal nondefibrinated plasma under the same conditions as used for the thrombin generation experiments.

\section{Phospholipid}

Phospholipid vesicles containing $20 \%$ phosphatidylserine (PS) and 80\% phosphatidylcholine (PC) were prepared as described by Rosing et al. [19].

\section{Proteins}

Bovine factor IX was prepared as described by Fujikawa et al. [20]. Bovine factor VIII was prepared according to Vehar and Davie [21] with the modifications by van Dieijen et al. [22].

\section{Chromogenic Substrate}

Chromogenic substrate S 2238 (HD-phe-pip-argp-nitrophenyl acetate, $2 \mathrm{HCl}$ ) was obtained from Kabi Vitrum (Stockholm, Sweden).

Measurement of Thrombin Generation in Plasma

For the measurement of thrombin generation the procedure described by Hemker et al. [16] was used. Briefly, $240 \mu \mathrm{l}$ of defibrinated plasma and $60 \mu \mathrm{l}$ of buffer (Tris- $\mathrm{HCl}, \mathrm{pH}$ 7.35) were incubated for $4 \mathrm{~min}$ at $37^{\circ} \mathrm{C}$. Thrombin generation was triggered by the addition of $60 \mu \mathrm{l}$ of thromboplastin solution containing $0.1 \mathrm{M} \mathrm{CaCl}_{2}$. At fixed time intervals, $10-\mu \mathrm{l}$ aliquots of the incubation mixture were subsampled into tubes containing $465 \mu \mathrm{l}$ of buffer $(0.05 M$ Tris$\mathrm{HCl}, 0.1 \mathrm{M} \mathrm{NaCl}, 0.5 \%$ albumin and $0.02 M$ EDTA, $\mathrm{pH} 7.9)$ and $25 \mu \mathrm{l}$ of $\mathrm{S} 2238(4 \mathrm{mM})$ at $37^{\circ} \mathrm{C}$. The subsampling tubes were incubated for $2 \mathrm{~min}$ at $37^{\circ} \mathrm{C}$, and then the reaction was stopped by the addition of $300 \mu$ l of concentrated acetic acid. The pipettes for sampling and stopping the reaction were connected to an Apple IIe computer, programmed to record the moment of sampling and the moment of stopping the reaction. The optical density was read at $405 \mathrm{~nm}$ in a spectrophotometer (LKB-Ultrospec). From the change in optical density and the time interval between subsampling and stopping the $\Delta O D / \mathrm{min}$ was automatically calculated.

\section{Measurement of the Decay Constant of \\ Endogenous Thrombin and Estimation of the \\ Prothrombin Conversion Velocity}

In order to calculate the course of prothrombinase activity from the thrombin generation curves, we determined the decay constant of endogenous thrombin in the plasma used; it was $1.19 \mathrm{~min}^{-1}$. This decay constant is the sum of the decay constant of thrombin by non- $\alpha_{2}$-macroglobulin $\left(\alpha_{2} M\right)$ antiproteases essentially antithrombin III $\left(\mathrm{k}_{1}\right)$ and the decay constant of thrombin by $\alpha_{2} \mathrm{M}\left(\mathrm{k}_{2}\right)$. Because the hemophilia $B$ plasma contained a normal concentration of $\alpha_{2} \mathrm{M}$, we adopted as $\mathrm{k}_{2}$ the decay constant determined in normal plasma $\left(\mathrm{k}_{2}=0.232 \pm 0.004 \mathrm{~min}^{-1} ; \mathrm{n}=25\right)$ [16].

According to Hemker et al. [16], the prothrombin conversion velocity (prothrombinase activity, expressed in nanomoles thrombin formed per minute) was calculated from the thrombin generation data and the experimentally determined decay constants of endogenous thrombin. The calculation is based on the fact that at any moment the experimentally observed rate of change of the thrombin concentration is the sum of the prothrombin conversion velocity and the thrombin decay velocity. The latter can be calculated from the thrombin concentration and the pseudo first-order decay constants. The fact that part of the thrombin converts to an amidolytically active $\alpha_{2} \mathrm{M}$ thrombin complex is accounted for.

\section{Results}

Generation of Thrombin Activity and

Prothrombinase Activity in

Factor-Deficient Plasma after Triggering

Coagulation with Different

Concentrations of Tissue Factor

The thrombin formation was studied either in factor-IX-deficient plasma (hemophilia B plasma) or deficient plasma reconstituted with purified factor IX as control. The coagulation was initiated with different 


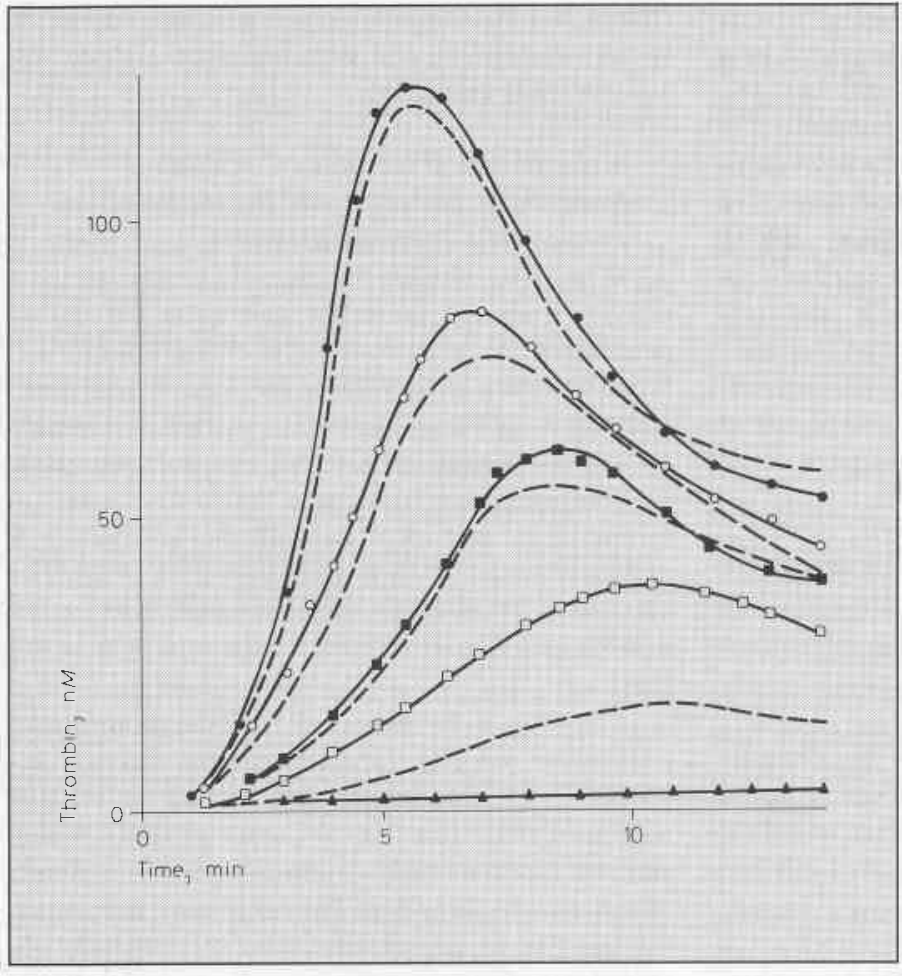

Fig. 1. Generation of thrombin activity in factor-IX-deficient plasma before and after reconstitution with factor IX $(90 \mathrm{n} M)$. Coagulation was triggered with a series of dilutions of thromboplastin in calcium chloride, and phospholipid was added to a fixed final concentration of $1 \mu M$. Final thromboplastin dilution in the reaction mixtures: $1 / 240(\bullet) ; 1 / 360(0) ; 1 / 480$ (Ш); $1 / 600$ (ㅁ); $\mathrm{CaCl}_{2}$ solution without thromboplastin (४). The continuous lines represent the results obtained with hemophilic plasma to which $90 \mathrm{n} M$ factor IX was added. The dashed line directly under the continuous line represents the data obtained with hemophilic plasma without addition. The experimental points are omitted in order not to overload the figure. dilutions of tissue thromboplastin in $0.1 \mathrm{M}$ $\mathrm{CaCl}_{2}$. At these dilutions, the addition of factor IX did not influence the generation of thrombin (results not shown).

In order for the phospholipid concentration not to be rate limiting, we then added a final concentration of $1 \mu M$ PS/PC (20/ 80 mole \%) to all the experiments. The highest concentration of tissue thromboplastin added contributed $0.022 \mu M$ of phospholipids, so that the change in phospholipid concentration brought about by dilution of tissue tromboplastin could be neglected. When the phospholipid was added without tissue thromboplastin, no thrombin generation was observed (fig. 1). From this observation, we conclude that the phospholipid mixture per se does not initiate thrombin formation.
Contact activation is negligible in our system due to consistent use of plastic material throughout the experiment.

Figure 1 shows that under these conditions the maximal amount of thrombin formed is greater in the reconstituted plasma than in plasma of patients with congenital factor IX deficiency and that the influence of factor IX on thrombin generation is more important at low thromboplastin concentrations.

When we calculated prothrombinase activities as a function of time and then plotted the peak prothrombinase activity as a function of the thromboplastin dilution we obtained the graph shown in figure 2.

It can be seen from figure 2 that at thromboplastin dilutions greater than 1:480, the 
prothrombinase plasma activity in plasma of patients with congenital factor IX deficiency is lower than that in reconstituted plasma.

\section{Factor IX and Factor VIII Dependency of}

Prothrombinase Activity after Triggering

\section{Coagulation with Thromboplastin}

In order to investigate the factor IX dependency of thrombin generation after triggering coagulation with thromboplastin, various quantities of factor IX (15-90 $\mathrm{n} M)$ were added to plasma of patients with congenital factor IX deficiency. After addition of phospholipid vesicles $(1 \mu M)$ coagulation was triggered with thromboplastin (final dilution 1:600). The peaks of prothrombinase activity were calculated from the thrombin generation curves (fig. 3 ).

It is clearly seen in this figure that in the concentration range tested, factor IX stimulates prothrombinase activity. The curve suggests a saturation type relationship between the factor IX concentration and prothrombinase activity. If normal prothrombinase activity is defined as to the activity at $100 \%(90 \mathrm{nM})$ of factor IX, half normal activity was observed at around $15 \mathrm{n} M$ factor IX (20\%).

In order to determine the factor VIII dependency of thrombin generation after triggering coagulation with thromboplastin, various quantities of factor VIII $(0.2-1 \mathrm{U} / \mathrm{ml})$ were added to the plasma of patients with congenital factor VIII deficiency. Additional phospholipids $(1 \mu M)$ were again added to the plasma preparation and the coagulation was triggered with thromboplastin (final dilution 1:600). The peak activities of prothrombinase thus obtained are shown in figure 4.

Increase of the factor VIII concentration stimulates thrombin generation and again

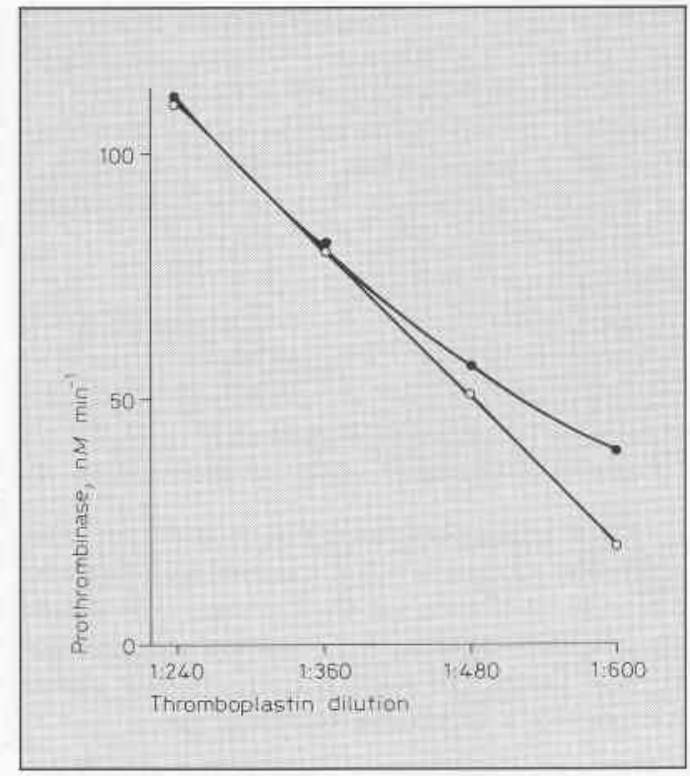

Fig. 2. Maximal prothrombinase activity in factor-IX-deficient plasma before and after reconstitution with factor IX $(90 \mathrm{n} M)$. Coagulation was triggered with a series of dilutions of thromboplastin in calcium chloride, and phospholipid was added to a fixed final concentration of $1 \mu M . \circ=$ Factor-IX-deficient plasma; $\bullet=$ reconstituted plasma.

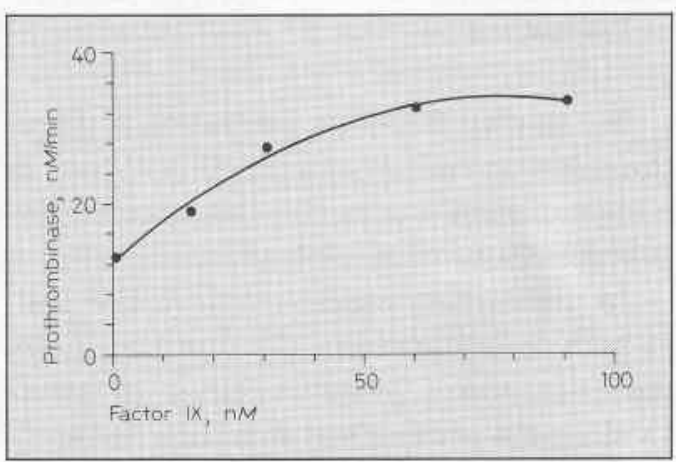

Fig. 3. Influence of factor IX on prothrombinase generation. Coagulation was triggered with thromboplastin (final dilution 1/600) in calcium chloride and phospholipid was added to a fixed final concentration of $1 \mu \mathrm{M}$. Factor IX added to the hemophilic plasma is expressed in $\mathrm{n} M / \mathrm{ml}$ (final concentration). 


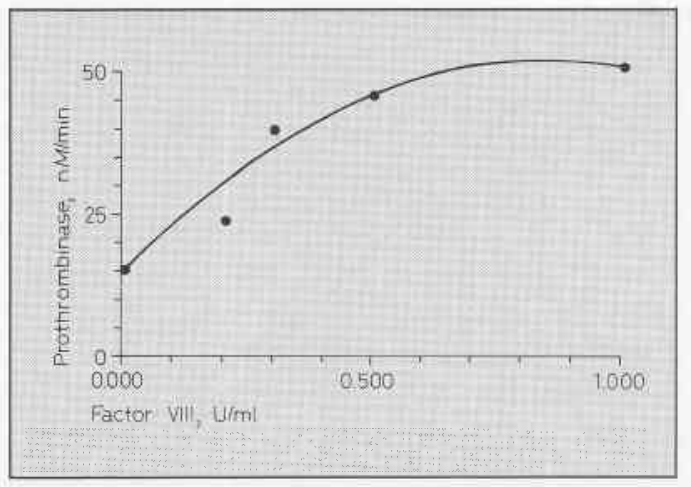

Fig. 4. Influence of factor VIII on prothrombinase generation. Coagulation was triggered with thromboplastin (final dilution 1/600) in calcium chloride and phospholipid was added to a fixed final concentration of $1 \mu \mathrm{M}$. Factor VIII added to the hemophilic plasma is expressed in $\mathrm{U} / \mathrm{ml}$ (final concentration).

the dependency appears to show saturation characteristics. Half normal prothrombinase activity was obtained at about $20 \%$ of factor VIII.

\section{Discussion}

We studied thrombin generation and prothrombinase activity as a function of time in human plasma under the influence of low concentrations of thromboplastin.

In preliminary experiments we saw that, at high thromboplastin dilution $(>1 / 600)$, the generation of thrombin activity in factorIX-deficient plasma was markedly reduced. This result is in accordance with the observation of Biggs and Nossel [6] who reported abnormal thrombin generation in plasma of both hemophilia A and hemophilia B patients after triggering coagulation with low amounts of thromboplastin. When, however,
$1 \mu M$ of phospholipid vesicles was added to the factor-IX-deficient plasma so as to make thrombin generation independent of the changes in phospholipid concentration brought about by dilution of thromboplastin, the importance of factor IX in the process of thrombin generation after triggering coagulation with small amounts of thromboplastin became evident. We therefore carried out all subsequent experiments in the presence of $1 \mu M$ phospholipid.

Figures 1 and 2 show clearly that the influence of factor IX on prothrombinase activity and hence on thrombin generation is more outspoken at higher thromboplastin dilutions. Evidently, in situations where lower amounts of thromboplastin are available, the interaction between intrinsic and extrinsic pathway becomes increasingly important.

The role of factor VIII as a cofactor in the factor X activation by factor IXa has been studied well. In the absence of factor VIIIa the rate of factor $\mathrm{X}$ activation by factor IXa is extremely low, even in the presence of a sufficient amount of phospholipids. Factor VIII brings about a $2 \cdot 10^{5}$-fold increase in the rate of factor $\mathrm{X}$ activation by factor IXa [2225].

The stimulating effects of factor VIII and factor IX on prothrombinase activity after triggering coagulation with small amounts of thromboplastin are comparable; the phenomenon showing saturation characteristics is represented in figures 3 and 4 .

At the high thromboplastin concentrations used in routine prothrombin tests, the influence of factors VIII and IX is not seen. These tests bypass the factor VII/thromboplastin-factor IX pathway, because the direct activation of factor $\mathrm{X}$ by factor VIIa tissue thromboplastin is fast. Therefore plasma 
from hemophiliacs will show a normal prothrombin time.

The interaction between the intrinsic and the extrinsic pathways of coagulation might explain several clinical observations. Some patients with a deficiency of factor VII have a serious hemorrhagic diathesis, whereas patients with deficiencies in the contact activation system have no significant bleeding tendency, but on the contrary may suffer thromboembolic episodes. The first patient with Hageman trait described in the literature died of pulmonary embolism [26]. The clinical behavior of factor-XI-deficient individuals, some of whom are asymptomatic, whereas others have a serious bleeding tendency, remains enigmatic.

The results presented here show the importance of factors IX and VIII in the thromboplastin-dependent coagulation process in those situations in which trace amounts of thromboplastin are present. If we admit that in vivo triggering of thrombin formation by low amounts of thromboplastin is the rule rather than the exception, this might explain why in hemophiliacs the deficiencies of the intrinsic pathway are not compensated by the intact extrinsic pathway.

Circumstantial evidence for this view may be obtained by the clinical observation that hemophiliacs tend to bleed in thromboplastin-poor organs like muscles and joints rather than in thromboplastin-rich organs like the lungs and brain [27].

As Josso and Prou-Wartelle [7] were the first to unequivocally demonstrate the role of the antihemophilic factors in the extrinsic pathway, we propose to call the factor-VIIIand IX-dependent prothrombinase formation induced by tissue thromboplastin the 'Josso pathway' in honor of the late François Josso, professor of haematology in Paris.

\section{Acknowledgements}

We thank Dr. M. van Dam-Mieras for critically reading and ameliorating the manuscript, Paul Devilée for expert technical assistance and Trees Camphuisen-Engel for preparation of this manuscript.

\section{References}

1 Macfarlane, R.G.: An enzyme cascade in the blood clotting mechanism, and its function as a biochemical amplifier. Nature 202: 498-499 (1964).

2 Davie, E.W.; Ratnoff, O.D.: Waterfall sequence for intrinsic blood clotting. Science $145: 1310$ 1312 (1964).

3 Niewarowski, S.; Bankowsi, E.: Studies on the adsorption and activation of factor XII. Thromb. Diath. haemorrh. 14: 387 (1965).

4 Griffin, J.H.; Harper, A.: Studies on the activation of human blood coagulation factor XI by soluble collagen. Fed. Proc. 34: 860 (1975).

5 Jesty, J.; Nemerson, Y.: Purification of factor VII from bovine plasma. Reaction with tissue factor and activation of factor X. J. biol. Chem. 249: 509-515 (1974).

6 Biggs, R.; Nossel, H.L.: Tissue extract and the contact reaction in blood coagulation. Thromb. Diath. haemorrh. 6: (1961).

7 Josso, F.; Prou-Wartelle, O.: Interaction of tissue factor and factor VII at the earliest phase of coagulation. Thromb. Diath. haemorrh., suppl. 17, pp. 35-44 (1965).

8 Østerud, B.; Rapaport, S.I.: Activation of factor IX by the reaction product of tissue factor and factor VII: additional pathway for initiating blood coagulation. Proc. natn. Acad. Sci. USA 74: 52505269 (1977).

9 Jesty, J.; Silverberg, S.A.: Kinetics of the tissue factor-dependent activation of coagulation factors IX and $\mathrm{X}$ in a bovine plasma system. J. biol. Chem. 254: 12337-12345 (1979).

10 Østerud, B.; Rapaport, S.: Activation of ${ }^{125} \mathrm{I}$-factor IX and ${ }^{125} \mathrm{I}$-factor X: effect of tissue factor and factor VII, factor Xa and thrombin. Scand. J. Haematol. 24: 213-226 (1980).

11 Zur, M.; Nemerson, Y.: Kinetics of factor IX activation via the extrinsic pathway. J. biol. Chem. 255: 5703-5707 (1980). 
12 Marlar, R.A.; Griffin, J.H.: Alternative pathways of thromboplastin-dependent activation of human factor $\mathrm{X}$ in plasma. Ann. N.Y. Acad'Sci. 370: 325-335 (1981).

13 Marlar, R.A.; Kleiss, A.J.; Griffin, J.H.: An alternative extrinsic pathway of human blood coagulation. Blood 60: 1353-1358 (1982).

14 Morrison, S.A.; Jesty, J.: Tissue factor dependent activation of tritium-labeled factor IX and factor $\mathrm{X}$ in human plasma. Blood 63: 1338-1347 (1984).

15 v.d. Besselaar, A.M.H.P.; Ram, I.E.; Alderkamp, G.H.J.; Bertina, R.M.: The role of factor IX in tissue thromboplastin-induced coagulation. Thromb. Haemostasis 48: 54-58 (1982).

16 Hemker, H.C.; Willems, G.M.; Béguin, S.: A computer assisted method to obtain the prothrombin activation velocity in whole plasma independent of thrombin decay processes. Thromb. Haemostasis 56: 9-17 (1986).

17 Josso, F.; Prou-Wartelle, O.: Exploration de l'hémostase; in Techniques en hématologie pp. 101208 (Flammarion, Paris 1972).

18 van Dam-Mieras, M.C.E.; Muller, A.D.; van Dieijen, G.; Hemker, H.C.: in Bergmeyer, Methods of enzymatic analysis. Enzymes 3: Peptidases, proteinases and their inhibitors, vol. V, pp. 352394 (Verlag Chemie, Weinheim 1984).

19 Rosing, J.; Tans, G.; Govers-Riemslag, J.W.P.; Zwaal, R.F.A.; Hemker, H.C.: The role of phospholipids and factor $\mathrm{Va}$ in the prothrombinase complex. J. biol. Chem. 255: 274-283 (1980).

20 Fujikawa, K.; Legaz, M.E.; Kato, H.; Davie, E.W.: The mechanism of activation of bovine factor IX (Christmas factor) by bovine factor XIa (activated plasma thromboplastin antecedent). Biochemistry 13: 4508-4516 (1974).
21 Vehar, G.A.; Davie, E.W.: Preparation and properties of bovine factor VIII. Biochemistry 19: 401-410 (1980).

22 van Dieijen, G.; van Rijn, J.L.M.L.; GoversRiemslag, J.W.P.; Hemker, H.C.: Assembly of the intrinsic factor $\mathrm{X}$ activating complex; interactions between factor IXa, factor VIIIa and phosphlipid. Thromb. Hamostasis 53: 396-400 (1985).

23 Hultin, M.B.; Nemerson, Y.: Activation of factor $\mathrm{X}$ by factors IX and VIII; A specific assay for factor IXa in the presence of thrombin-activated factor VIII. Blood 52: 928-940 (1978).

24 Hultin, M.B.: Role of human factor VIII in factor $\mathrm{X}$ activation. J. clin. Invest. 69: 950-958 (1982).

25 van Dieijen, G.; Tans, G.; Rosing, J.; Hemker, H.C.: The role of phospholipid and factor VIIIa in the activation of bovine factor X. J. biol. Chem. 256: 3433-3442 (1981).

26 Ratnoff, O.D.; Russe, R.J.; Scheon, R.P.: The demise of John Hageman. New Engl. J. Med. 279: 760-762 (1968).

27 Hemker, H.C.: Why do hemophiliacs bleed? In Memory of François Josso. Scand. J. Haematol., suppl. 40. pp. 33, 11-19 (1984).

Received: March 13, 1989

Accepted: April 5, 1989

Prof. Dr. H.C. Hemker

University of Limburg

Department of Biochemistry

NL-6200 MD Maastricht (The Netherlands) 